\title{
A coastal transect of McMurdo Dry Valleys (Antarctica) snow and firn: marine and terrestrial influences on glaciochemistry
}

\author{
B.R. WILLIAMSON,${ }^{1}$ K.J. KREUTZ, ${ }^{1}$ P.A. MAYEWSKI, ${ }^{1}$ N.A.N. BERTLER, ${ }^{1,2}$ S. SNEED, ${ }^{1}$ \\ M. HANDLEY, ${ }^{1}$ D. INTRONE ${ }^{1}$ \\ ${ }^{1}$ Climate Change Institute and Department of Earth Sciences, University of Maine, Sawyer Environmental Research Building, \\ Orono, Maine 04473, USA \\ E-mail: bruce.williamson@maine.edu \\ ${ }^{2}$ Antarctic Research Centre, Victoria University of Wellington, PO Box 600, Wellington, New Zealand
}

\begin{abstract}
Samples of snow and firn from accumulation zones on Clark, Commonwealth, Blue and Victoria Upper Glaciers in the McMurdo Dry Valleys $\left(\sim 77-78^{\circ} \mathrm{S}, 161-164^{\circ} \mathrm{E}\right)$, Antarctica, are evaluated chemically and isotopically to determine the relative importance of local (site-specific) factors vs regional-scale influences in defining glaciochemistry. Spatial variation in snow and firn chemistry confirms documented trends within individual valleys regarding major-ion deposition relative to elevation and to distance from the coast. Sodium and methylsulfonate $\left(\mathrm{MS}^{-}\right)$, for example, follow a decreasing gradient with distance from the coast along the axis of Victoria Valley (350-119 $\mu \mathrm{g} \mathrm{L}^{-1}$ for $\mathrm{Na}^{+}$; 33-14 $\mu \mathrm{g} \mathrm{L}^{-1}$ for $\mathrm{MS}^{-}$); a similar pattern exists between Commonwealth and Newall Glaciers in the Asgaard Range. When comparing major-ion concentrations (e.g. $\mathrm{Na}^{+}, \mathrm{MS}^{-}, \mathrm{Ca}^{2+}$ ) or trace metals (e.g. $\mathrm{Al}, \mathrm{Fe}$ ) among different valleys, however, site-specific exposures to marine and local terrestrial chemical sources play a dominant role. Because chemical signals at all sites respond to particulates with varying mixtures of marine and terrestrial sources, each of these influences on site glaciochemistry must be considered when drawing temporal climate inferences on regional scales.
\end{abstract}

\section{INTRODUCTION}

The individual glacier accumulation zones of the McMurdo Dry Valleys (MDV), southern Victoria Land, provide a unique opportunity to study the interplay between localand regional-scale spatial trends in coastal Antarctic climate. Several studies in the region reveal that a combination of marine and continental air masses influences local climate, with seasonality, external forcing and site-specific factors creating diverse boundary conditions (Welch and others, 1993; Mayewski and others, 1995; Doran and others, 2002; Bertler and others, 2004a, b, 2005b, 2006). In addition to information regarding local climate, there is a growing body of literature examining regional- to hemispheric-scale climate change using ice-core records from Newall Glacier in the MDV and from Taylor Dome, $<75 \mathrm{~km}$ distant (Landis and others, 1995; Mayewski and others, 1995, 1996; Stager and Mayewski, 1997; Sucher, 1997; Steig and others, 1998a, b, 2000). The Dry Valleys are of particular interest because this region contains records of marine, aeolian, lacustrine and fluvial processes within a small geographic area (Hall and others, 2000, 2002; Armienti and others, 2001; De Carlo and Green, 2002; Lancaster, 2002; Green and others, 2005; Hall and Denton, 2005). Although the area is perhaps best known for environmental research on the exposed valley floors, there are several alpine glaciers residing on ridges separating the individual valleys. Ice cores from sites on several of these glaciers have provided records of atmospheric chemistry showing connections between local snow and ice composition and marine ionic chemistry (Mayewski and others, 1995; Lyons and others, 2003), marine biological activity and sea-ice extent (Welch and others, 1993), and local aerosol transport (Mayewski and Lyons, 1982; Bertler and others, 2004b).
In particular, a number of researchers have discussed major-ion chemistry in Dry Valleys snow and ice (Mayewski and others, 1995; Lyons and others, 2003; Bertler and others, 2004b), and in some cases have examined trace metals as well (Mayewski and Lyons, 1982; Bertler and others, 2004b). All agree that local insoluble material plays a significant role in shaping the distribution of chemistry in MDV samples, and that dry periods combined with high winds likely deposit significant amounts of both soluble and insoluble species to glacier surfaces (Mayewski and Lyons, 1982; Mayewski and others, 1995; Lyons and others, 2003; Bertler and others, 2004b). Refining the nature of these wind patterns through examination of major-ion, $\mathrm{Al}$ and Fe input timing on Victoria Lower Glacier, Bertler and others (2004b) found that, with few exceptions, concentration maxima occur at the same time for marine and terrestrial elements. They associated these shared maxima with a 'monsoonal' circulation in the climate of the Dry Valleys and suggested that local chemistry thus provides a glaciochemical record of onshore-offshore wind patterns known to function in modern MDV meteorology (Thompson and others, 1971; McKendry and Lewthwaite, 1990; Doran and others, 2002; Bertler and others, 2004b).

This paper focuses on evidence used to isolate local input of aerosols to MDV glaciers, including effects based on different site exposures to marine airflow and proximity to different soil sources, from the effects of regional geographic variables such as distance from the coast or elevation. This search is complicated by the fact that significant concentrations of the analytes found in MDV ice derive both from marine species associated with the nearby Ross Sea and from soluble and insoluble materials present within the valleys (Mayewski and Lyons, 1982; Welch, 1993; Welch and others, 1993; Mayewski and others, 1995; Lyons and others, 2003; Bertler and others, 2004b). Interpreting 


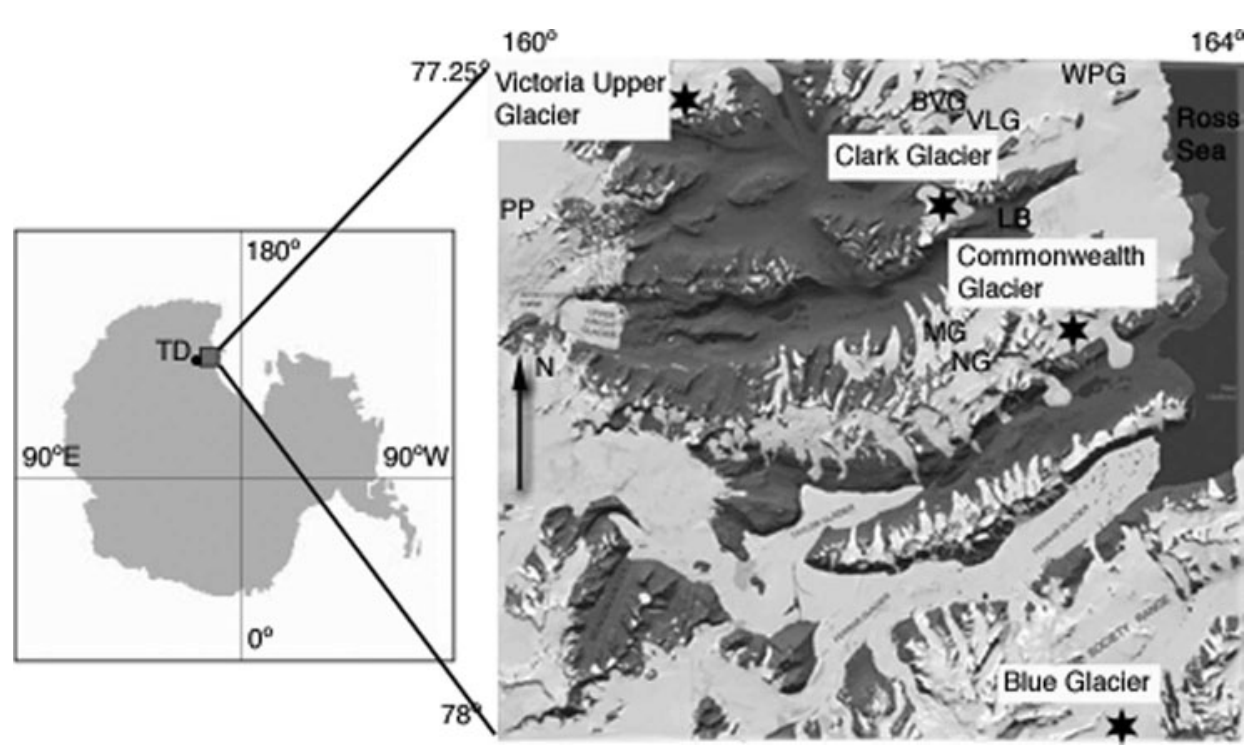

Fig. 1. Index map showing locations of Victoria Upper, Clark, Commonwealth and Blue Glaciers. Base map by GeographX, 2006.

chemical records in this area therefore requires techniques to separate these local terrestrial signals from the regional marine signal.

Among the four sites discussed in this paper, the first three lie along a north-south transect within $30 \mathrm{~km}$ of the coast and are in close proximity to three of the primary valleys in the MDV network (Victoria, Wright and Taylor Valleys) and three smaller $(\sim 10 \mathrm{~km})$ valleys (Garwood, Marshall and Miers Valleys) (Fig. 1). The fourth site is located at the western end of Victoria Valley, near the junction between the polar plateau and the MDV. To assess trends in chemistry from these sites, mean concentration values for a selection of analytes are first evaluated to provide a picture of spatial variation in snow and ice chemistry on a local scale (within the accumulation zones of Clark and Commonwealth Glaciers) and on a regional scale (among the four sites). These mean values and the relationships between them are also compared with similar surveys conducted within individual valleys by other investigators. Several investigators in Antarctica and in the MDV have demonstrated links between species concentrations, elevation, distance from the coast, and distance to the sea-ice edge (Legrand and Delmas, 1984, 1988; Welch and others, 1993; Mulvaney and Wolff, 1994; Kreutz and Mayewski, 1999; Lyons and others, 2003; Bertler and others, 2004b, 2005b). However, these trends are not present within this dataset, indicating that within the MDV different soil sources and site exposures provide stronger influences on site chemistries along a north-south axis than do these regional-scale parameters. Because the sites in this study represent different valleys within the MDV, we can examine these intra-valley effects and compare them with effects previously cataloged within individual valleys.

\section{FIELD SAMPLING LOCATIONS AND TECHNIQUES}

Samples for this study were collected from accumulation zones on Clark Glacier $\left(77.4054^{\circ} \mathrm{S}, 162.3656^{\circ} \mathrm{E}\right.$; $816 \mathrm{~m}$ a.s.l.), Commonwealth Glacier $\left(77.5423^{\circ} \mathrm{S}\right.$, $163.0226^{\circ} \mathrm{E} ; 723 \mathrm{~m}$ a.s.I.), Blue Glacier $\left(78.0830^{\circ} \mathrm{S}\right.$, 163.2932 ${ }^{\circ}$; $\left.1022 \mathrm{ma.s.I.}\right)$ and Victoria Upper Glacier $\left(77.3005^{\circ} \mathrm{S}, 161.0419^{\circ} \mathrm{E} ; 1350 \mathrm{ma.s.l}.\right)$, located in the
Olympus, Asgaard, Royal Society and Clare Ranges, respectively. Snow pits were excavated in November 2003 at Clark, Commonwealth and Blue locations and in November 2004 at Victoria Upper Glacier as part of efforts to determine suitability for collection of medium-depth ice cores.

Snow pits at Clark, Blue and Victoria Upper Glaciers were dug to depths of 226, 224 and $200 \mathrm{~cm}$, respectively; the pit at Commonwealth Glacier was dug to $304 \mathrm{~cm}$. One wall of each pit was prepared for sampling by first removing the outer $10 \mathrm{~cm}$ of firn with a clean plastic shovel and then scraping with a pre-rinsed plastic scraper to remove another $2 \mathrm{~cm}$ of material to avoid contamination. During this preparation process and the sampling process, the person collecting samples wore a Tyvek ${ }^{\circledR}$ clean suit and two pairs of clean polyethylene gloves. Using pre-cleaned titanium tools, samples were collected at $2 \mathrm{~cm}$ intervals for major-ion and isotopic analysis and at $10 \mathrm{~cm}$ intervals for trace element analysis. A higher-volume lower-resolution sample was collected for trace metals to allow multiple tests of trace elements from each interval (Williamson, 2006) while staying within the lateral area associated with the data for the major ions.

Each major-ion and isotope sample was collected into one $60 \mathrm{~mL}$ polypropylene cup and each trace element sample was collected into a separate $500 \mathrm{~mL}$ polypropylene bottle. Major-ion/isotope containers were cleaned before use by rinsing three times with deionized water $(>18 \mathrm{M} \Omega \mathrm{cm}$ resistivity), soaking for $>8$ hours in deionized water, rinsing again three times and drying in a clean laminar flow bench for 2 hours. Trace metal containers were soaked in $10 \%$ $\mathrm{HNO}_{3}$ for 24 hours, rinsed once, soaked for 24 hours and rinsed again in deionized water before drying on the clean bench. After collection, samples were maintained at $-20^{\circ} \mathrm{C}$ and shipped back to the University of Maine Climate Change Institute for analysis.

Borehole temperature data were collected using an RBR model TR-1050P temperature logger lowered into boreholes on Clark, Commonwealth and Victoria Upper Glaciers during November 2005. The temperatures presented here represent equilibration for a minimum of $45 \mathrm{~min}$ at selected ice depths. 
Mass-balance pole networks included 4 pole $\times 5$ pole grids on Clark and Commonwealth Glaciers with $200 \mathrm{~m}$ spacing between poles, and a 3 pole $\times 3$ pole grid on Victoria Upper Glacier with $100 \mathrm{~m}$ spacing. These networks were left in place between the 2004 and 2005 seasons, yielding 1 year of data. Mass-balance poles were also installed in the 2003 season at Clark, Commonwealth and Blue Glaciers, with greater and more irregular pole spacing ( $500 \mathrm{~m})$; 2004/05 data for Blue Glacier come from the measurements of these poles in November 2005. Massbalance data collected by the Long-Term Ecological Research (LTER) group for Commonwealth Glacier are included here for comparison during time periods not covered by the above networks (A.G. Fountain, http:// metacat.Iternet.edu $/ \mathrm{knb} /$ metacat?action=read\&qformat= $\mathrm{mcm} \&$ docid=knb-Iter-mcm.2008). Though there have been more than 20 LTER poles monitored on Commonwealth Glacier on an intermittent basis, only four were located within $1500 \mathrm{~m}$ of the snow pit in areas which likely shared similar accumulation histories with the pit. Only data from these four poles were used to maximize the likelihood that pole data represented similar accumulation histories to those determined at the pit location.

\section{CHEMICAL AND ISOTOPIC ANALYSIS}

Major-ion analysis was conducted using Dionex ${ }^{\mathrm{TM}}$ DX-100 ion chromatographs (ICs) after samples were melted and transferred via pipette to $5 \mathrm{~mL}$ mailing tubes used to introduce samples onto the column of the IC. These pipettes and mailing tubes were cleaned according to the same procedures used for the original sample containers. Anions $\left(\mathrm{MS}^{-}, \mathrm{Cl}^{-}, \mathrm{NO}_{3}^{-}, \mathrm{SO}_{4}{ }^{2-}\right.$ ) were measured using an $\mathrm{AS}-11$ column and a Dionex ${ }^{\mathrm{TM}}$ Reagent Free Controller producing a $\mathrm{KOH}$ eluent gradient of $1-8 \mathrm{mM}$. Cations $\left(\mathrm{Na}^{+}, \mathrm{K}^{+}, \mathrm{Mg}^{2+}\right.$, $\mathrm{Ca}^{2+}$ ) were measured using a CS-12A column with $25 \mathrm{mM}$ methanesulfonic acid eluent. In addition to samples, ten deionized water blanks were analyzed using the same methods. Values for the blanks were $<1 \%$ of the lowest sample values for all species except for $\mathrm{K}^{+}$, for which three of the blanks had values $\sim 13 \%$ of the lowest sample or $\sim 2 \%$ of the mean sample value. Duplicates were run every 20th sample; sample variability was $<5 \%$ for all duplicates for all species except for $\mathrm{Ca}^{2+}(11 \%)$ and $\mathrm{SO}_{4}{ }^{2-}(5.3 \%)$.

${ }^{2} \mathrm{H} /{ }^{1} \mathrm{H}$ isotope ratios were determined using gas source mass spectrometry conducted on a Micromass Isoprime system configured for continuous flow, fitted with a EuroVector Pyr OH furnace and liquid autosampler running DataLynx software. Values are reported as a difference relative to the Standard Mean Ocean Water (SMOW) standard according to the formula

$$
\delta D_{\text {SMOW }}(\%)=1000\left[\frac{\left(H_{2} / H_{1}\right)_{\text {SAMPLE }}-\left(H_{2} / H_{1}\right)_{\text {SMOW }}}{\left(H_{2} / H_{1}\right)_{\text {SMOW }}}\right] \text {. }
$$

The long-term precision and duplicate variability using laboratory and international standards was $0.5 \%$ for

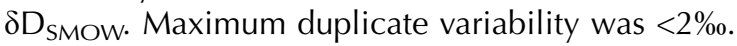

Trace metal concentrations were determined for samples from Clark, Commonwealth and Blue Glaciers using a ThermoFinnigan ELEMENT2 ${ }^{\mathrm{TM}}$ inductively coupled plasma mass spectrometer (ICP-MS) for $\mathrm{Ba}, \mathrm{Cd}, \mathrm{Co}, \mathrm{Cr}, \mathrm{Cs}, \mathrm{Cu}, \mathrm{Mn}$, $\mathrm{Pb}, \mathrm{Sr}, \mathrm{Ti}, \mathrm{U}, \mathrm{V}, \mathrm{Zn}$ and the rare-earth elements (REE). A Perkin-Elmer Optima $3000 \mathrm{XL}$ axial inductively coupled plasma optical emission spectroscope with a CETAC
(Omaha, USA) ultrasonic nebulizer (ICP-OES-USN) was used to determine values of $\mathrm{Al}, \mathrm{Ca}, \mathrm{Fe}$ and $\mathrm{S}$. For samples from Victoria Upper Glacier, concentrations of elements in both of the above lists were determined using ICP-MS. Preparation of samples for both instruments involved melting the original sample, agitating it to suspend sediment, and then immediately transferring an aliquot by pre-cleaned pipette from the original sample bottle to polypropylene analysis vials. For the ICP-MS the aliquot was $3.5 \mathrm{~mL}$, and for the ICP-OES the aliquot was $10 \mathrm{~mL}$. Analysis vials were then acidified to $1 \% \mathrm{HNO}_{3}$ using Fisher Optima ${ }^{\circledR}$ grade nitric acid to prevent material from plating to the vial walls. Based on runs of several metals using both methods, both sample magnitudes and trends are the same between ICPMS and ICP-OES; limited variability found among the data likely relates to different amounts of particles being captured in separate runs (Williamson, 2006). Because of overall good agreement, data from these two instruments are compared directly. Blank samples were again prepared using deionized water. For $\mathrm{Al}, \mathrm{Cu}, \mathrm{Fe}, \mathrm{Mn}, \mathrm{Pb}, \mathrm{S}, \mathrm{Sr}, \mathrm{Ti}$ and REE, blank values were $<10 \%$ of average sample values at all sites. In all statistical analyses presented below, elements that do not meet this standard are not used.

\section{RESULTS}

\section{Chronologies/accumulation rates}

Prior investigations in Antarctica have depended on a variety of techniques for dating chemical profiles, including chronostratigraphic radioactive layers from atomic bomb testing (Crozaz and others, 1966; Boutron, 1982; Mayewski and others, 1995; Bertler and others, 2004b), strain-thickness calculation (Mayewski and Lyons, 1982), visual stratigraphy (Boutron and Lorius, 1979), and seasonal variations in the concentration and relative proportions of $\mathrm{Na}^{+}, \mathrm{Cl}^{-}$, methylsulfonate $\left(\mathrm{MS}^{-}\right)$, and the stable isotopes of oxygen and hydrogen (Boutron, 1982; Welch and others, 1993; Kreutz and others, 2000; Steig and others, 2000, 2005; Bertler and others, 2004b; Dixon and others, 2005). For the sites described in this study, limitations exist for several of these methods. Deuterium ratios $\left(\delta^{2} \mathrm{H}\right)$, for example, are modified after deposition by a smoothing effect thought to be related to low accumulation rate and diffusion processes (Johnsen, 1977; Mayewski and others, 1995). Stratigraphy is not well defined at the Victoria Upper Glacier site below $25 \mathrm{~cm}$, with firn becoming homogeneous with large crystal size (diameter $=\sim 4 \mathrm{~mm}$ ). As at other Dry Valleys sites, no surface melting was visible above the firn containing these crystals (Lyons and others, 2003), and the top $25 \mathrm{~cm}$ appeared consistent with unmodified surface snowfall. Instead of liquid water at the surface, however, with firn densities in the top layers as low as $0.25 \mathrm{~g} \mathrm{~cm}^{-3}$, these conditions may represent subsurface melting (Brandt and Warren, 1993), and dictate caution in interpreting temporal trends at this site. While $\mathrm{MS}^{-}$has been used as a seasonal marker at some coastal sites in Antarctica (Legrand and Mayewski, 1997), this species has been associated with vertical migration between seasonal ice layers at other sites, making proposed chronologies more complex (Mulvaney and others, 1992; Legrand and Mayewski, 1997; Kreutz and others, 1998; Pasteur and Mulvaney, 1999, 2000; Curran and others, 2002; Smith and others, 2004). Given that glaciers in the Dry Valleys have low accumulation rates (Welch and others, 1993; Mayewski and 

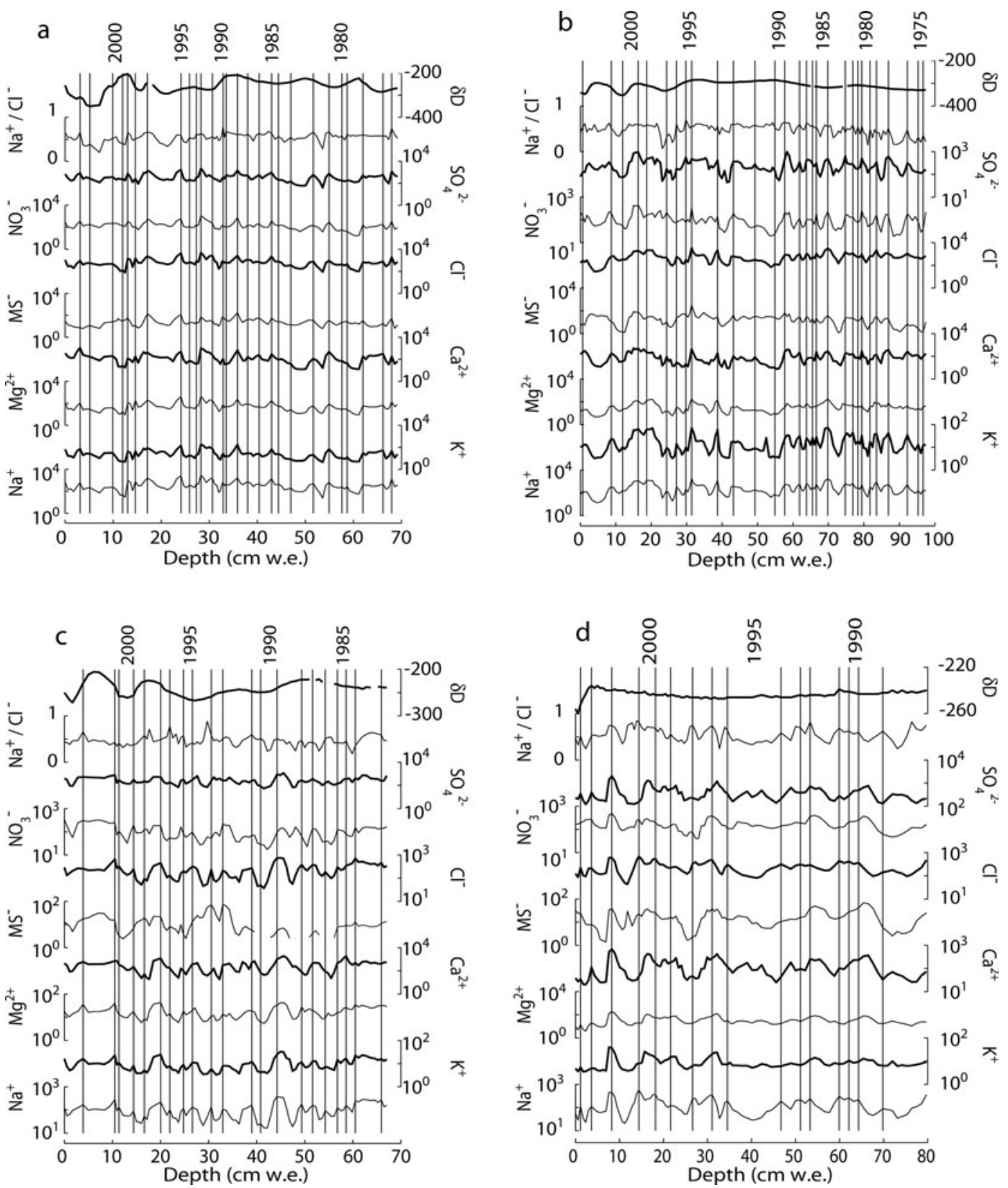

Fig. 2. Major ions and isotope ratios for (a) Clark Glacier, (b) Commonwealth Glacier, (c) Blue Glacier and (d) Victoria Upper Glacier plotted with dates corresponding to summer (December-February) peaks in sodium concentrations. Peaks are defined as snow or firn layers with concentrations $>10 \%$ higher than the layers above or below. Ion concentrations are reported as the absolute concentration in $\mu \mathrm{g} \mathrm{L}^{-1}$ (scaled logarithmically), and isotope ratio $\delta \mathrm{D}$ (= deuterium/hydrogen) is reported as \% V-SMOW (Vienna Standard Mean Ocean Water). Dating, supported by agreement with physical mass-balance measurements, is estimated to be accurate to \pm 1 year.

others, 1995; Bertler and others, 2004b), even a slight migration of $\mathrm{MS}^{-}$could have a significant effect.

Because of uncertainties with these other methods, variations in $\mathrm{Na}^{+}$concentration, which reflect seasonal signals at a variety of sites in Antarctica (Welch and others, 1993; Legrand and Mayewski, 1997; Kreutz and Mayewski, 1999; Kreutz and others, 2000; Bertler and others, 2004b), including the Dry Valleys (Welch and others, 1993; Bertler and others, 2004b), provide the most consistent chemical depth series with which to develop chronologies for the sites discussed here (Fig. 2). Snow-pit samples for this study were collected in November, during the Antarctic spring (here considered September-November), and eight of ten pits sampled in the 2003 and 2004 seasons yielded $\mathrm{Na}^{+}$values that decrease with depth in surface snow. These findings support the conclusion of Bertler and others (2004b) that peaks in $\mathrm{Na}^{+}$represent summer precipitation in the MDV, in contrast to winter $\mathrm{Na}^{+}$peaks found at many other sites in Antarctica (Legrand and Delmas, 1984; Wagenbach and others, 1998). Based on layer counting between peaks after adjusting for the density profile at each site, mean annual net mass balance is 2.5, 3.4, 3.1 and $4.6 \mathrm{~cm}$ water equivalent (w.e.) for Clark, Commonwealth, Blue and Victoria Upper Glaciers, respectively. The range of accumulations found within the depth series for each snow pit was $1-7 \mathrm{~cm}$ w.e. at Clark, Commonwealth and Blue Glaciers and 1-12 cm w.e. at Victoria Upper Glacier.

Networks of mass-balance poles installed near the four snow pits provide a complementary geophysical dataset with which to check accumulation-rate histories derived 
a

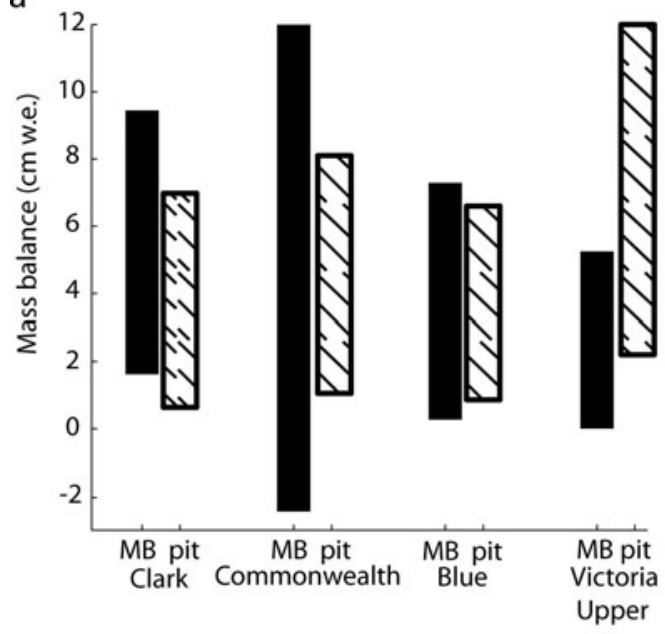

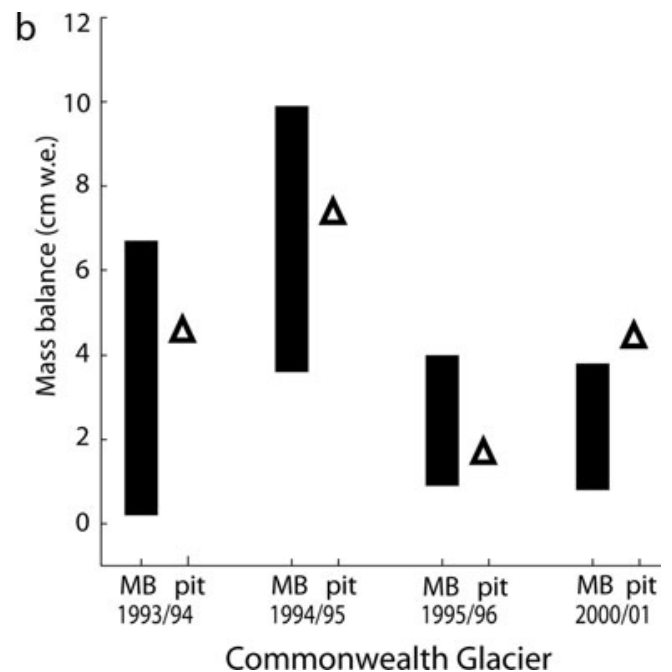

Fig. 3. Mass-balance comparisons between physical measurement of mass-balance poles $(\mathrm{MB})$ and mass differences between sodium peaks measured in snow pits (pit). In (a) the black lines represent the range of mass-balance pole measurements for the 2004/05 season (a spatial range) and the hatched lines represent the range of accumulations determined according to mass differences in sodium (temporal range). In (b) the black lines represent the range of LTER stakes $(n=4)$ in place on Commonwealth Glacier during each of these seasons (A.G. Fountain, http://mercury.ornl.gov/metadata/lter/html//ter/metacat.Iternet.edu_knb_metacat_action_read_qformat_xml_docid_knb-Iter$\mathrm{mcm} .2008 .2 \mathrm{html}$ ) and the open triangles represent the accumulation for the corresponding year derived using the data used to generate Figure 2.

from chemical measurements. Only pole data for the year 2004/05 are included to examine a common time period where data exist for all sites. The range of values for mass balance from pole networks agrees well with the range of mass-balance values derived from $\mathrm{Na}^{+}$measurements over the time period covered in the snow pits at all sites except for Victoria Upper Glacier (Fig. 3). However, as 2004/05 pole data represent a time period after the snow pit was sampled, they cannot provide a direct comparison of mass balance during the time period covered by the pits. At Commonwealth Glacier, on the other hand, the LTER massbalance network covers several years included in the chronology presented here (A.G. Fountain, http://metacat. Iternet.edu $/ \mathrm{knb} /$ metacat?action $=$ read \&qformat $=\mathrm{mcm} \&$ docid=knb-lter-mcm.2008). These values, when compared with the net mass accumulation value for the corresponding years in the snow pit, provide additional confirmation that chemistry-based accumulation rates fall within the range of mass balances calculated from physical measurements.

\section{Intra-site variability}

Major-ion concentrations measured in four pits separated by $\sim 800 \mathrm{~m}$ at Clark Glacier and from four similarly separated pits at Commonwealth Glacier provide a measure of intrasite variability. Mean values from snow and firn samples representing the time period 1996-2002 (depths 10-96 cm, depending on the pit) were used for this comparison at the Clark site; mean values from samples representing 2000-02 (depths $4-58 \mathrm{~cm}$ ) were used at the Commonwealth site. Concentrations within each of these sites vary across three orders of magnitude as they do at other locations in the Dry Valleys (Lyons and others, 2003; Bertler and others, 2004b); because lower concentrations are more prevalent than higher concentrations, indicative of a log-normal distribution, the geometric mean and standard deviation are presented here instead of the arithmetic mean and standard deviation.

Both ion concentrations $\left(\mu \mathrm{g} \mathrm{cm}^{-3}\right)$ and fluxes $\left(\mu \mathrm{g} \mathrm{cm}^{-2} \mathrm{a}^{-1}\right)$ were considered in all comparisons discussed here. Because concentration differences possibly can be interpreted as either a change in the amount of a given species arriving at a site or as a change in the accumulation of ice surrounding the species creating a dilution effect, accounting for the accumulation rate is necessary to determine whether a dilution effect exists at a given location (Mulvaney and Wolff, 1994; Yang and others, 1996; Kreutz and Mayewski, 1999). However, even accounting for annual accumulation rates, problems may still be encountered with individual storm events providing unique concentration signatures not necessarily well captured in a flux comparison calculated in this manner. In the case of the snow pits at these locations, the same statistically significant differences occur within and among the accumulation zones when either fluxes or concentrations are compared; because this indicates that a dilution effect is secondary, we use concentration values for the purposes of comparison. Mean $\mathrm{Na}: \mathrm{Cl}$ and $\mathrm{Ca}:(\mathrm{Na}+\mathrm{K}+\mathrm{Mg})$ ratios for each site are also examined to provide information regarding the relative importance of sea salt (with expected ratios of $\mathrm{Na}: \mathrm{Cl} \sim 0.86$ molar and $\mathrm{Ca}:(\mathrm{Na}+\mathrm{K}+\mathrm{Mg}) \sim 0.06$ molar $)$ vs local soils and other atmospheric sources in determining snow and firn chemistry (Mayewski and others, 1995; Lyons and others, 2003).

On both Clark and Commonwealth Glaciers, statistically significant differences are found in concentrations of multiple species within each accumulation zone (Fig. 4). Trends in chemistry are unrelated to geographic variables, and instead site-specific factors are assumed to influence these intra-site patterns (Williamson, 2006). Causes may include varying exposures both to marine influence and to material inputs from the nearby valley floors. An example of potential marine effects is evident in an examination of austral summer wind data from the 2000 season. During a common time period from that summer, for which wind direction measurements are available both from Lake Brownworth automatic weather station in Wright Valley (LB in Fig. 1) and from a similar weather station on the ice divide of Victoria Lower Glacier (VLG in Fig. 1), a split in ground-level wind 

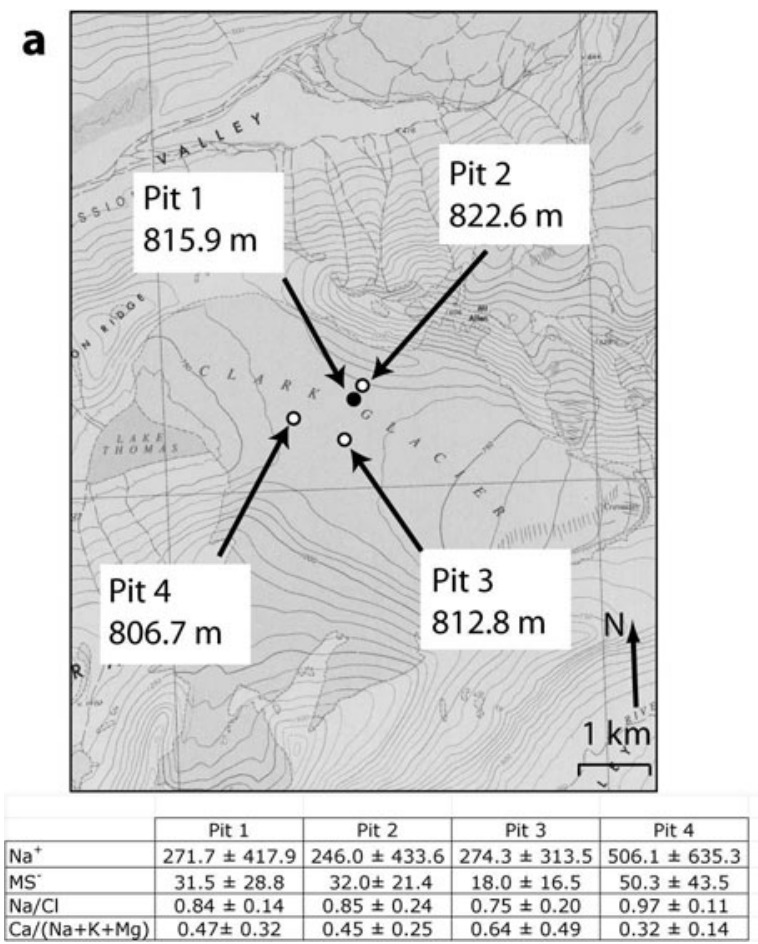

b
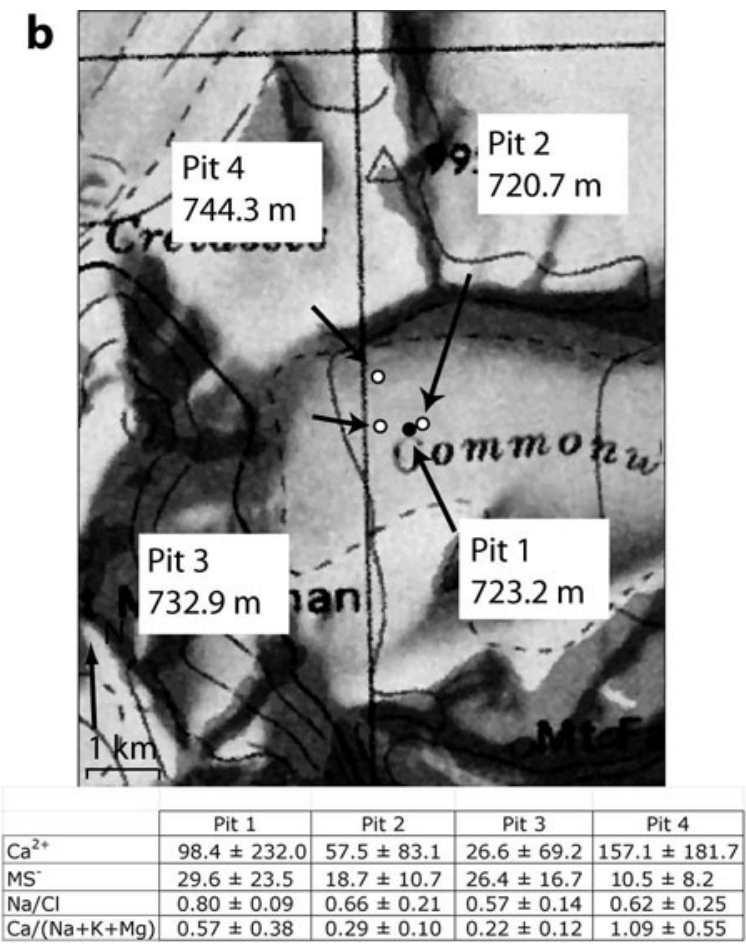

Fig. 4. Locations and selected geometric mean species concentrations (in $\mu \mathrm{g} \mathrm{L}^{-1}$ ) for multiple $1 \mathrm{~m}$ pits on (a) Clark Glacier and (b) Commonwealth Glacier. The primary pit excavated in 2003 is shown as the black circle. The three pits excavated in 2004 to explore spatial variability are shown as open circles. Statistical similarity was measured using $p$ values associated with two-tailed $t$ tests $(n=31,23$, 24 and 28 samples on Clark Glacier; $n=13,11,10$ and 11 samples on Commonwealth Glacier). Species concentration differences with $p<0.05$ are considered significant. On Clark Glacier, $\mathrm{Na}^{+}$and $\mathrm{MS}^{-}$concentrations were found to be significantly high at pit 4 relative to multiple pits. On Commonwealth Glacier, $\mathrm{Ca}^{2+}$ concentrations were high and $\mathrm{MS}^{-}$concentrations were low at pit 4 . The $\mathrm{Na}: \mathrm{Cl}$ and $\mathrm{Ca}:(\mathrm{Na}+\mathrm{K}+\mathrm{Mg})$ ratios also contained significant differences at pits 3 and 4 on Clark Glacier and for pits 1 and 4 on Commonwealth Glacier. Base maps US Geological Survey (USGS) Lake Brownworth quadrangle, 1977, and USGS Ross Island and Vicinity, 1986.

direction was active, with winds at Lake Brownworth flowing predominantly from the east-northeast while winds at Victoria Lower Glacier flowed predominantly from the east-southeast (Fig. 5) (Bertler and others, 2004b; A.G. Fountain, http://metacat.Iternet.edu/knb/metacat?action= read\&qformat $=$ mcm\&docid $=$ knb-Iter-mcm.7005). Lake Brownworth meteorological station measurements. knbIter-mcm.7005.1). This pattern suggests that onshore winds flow around Mount Allen, which lies between Clark Glacier and the Ross Sea to the northeast, altering local airflow. This pattern may explain why pit 4 on Clark Glacier (the lowestelevation pit, the closest to Victoria Valley and the farthest from the shelter of Mount Allen) contains significantly higher concentrations of $\mathrm{Na}^{+}$and $\mathrm{MS}^{-}$than do the other pits.

However, a direct marine influence does not explain significant variation in $\mathrm{Na}: \mathrm{Cl}$ ratios in the accumulation zone of both glaciers, or high $\mathrm{Ca}^{2+}$ values at pit 4 on Commonwealth Glacier. In addition, $\mathrm{Ca}$ : $(\mathrm{Na}+\mathrm{K}+\mathrm{Mg})$ values for all pits at both sites are an order of magnitude higher than marine values. These data require additional ion sources, and demonstrate that, on an intra-site scale, relative exposure to the materials of the nearby Wright and Victoria Valleys also contributes to different major-ion concentrations.

\section{Regional trends}

Major ions

Sodium derived from sea salt has provided records of marine activity around Antarctica, with $\mathrm{Cl}^{-}, \mathrm{K}^{+}, \mathrm{Mg}^{2+}, \mathrm{Ca}^{2+}$ and $\mathrm{SO}_{4}{ }^{2-}$ inputs being attributed in part to sea salt and in part to terrestrial and atmospheric sources (Legrand and Delmas,
1988; Mulvaney and Wolff, 1994; Legrand and Mayewski, 1997; Kreutz and Mayewski, 1999; Kreutz and others, 2000). Similarly, within the MDV, the seasonality of the $\mathrm{Na}^{+}$ signal and the delineation by previous investigators of negative concentration gradients with distance from the coast along valley transects suggest that $\mathrm{Na}^{+}$variation in MDV ice reflects marine influence (Lyons and others, 2003; Bertler and others, 2004b). The data from the four sites discussed here support this conclusion as long as the data are examined within individual valley systems.

Mean ion concentrations from snow and firn representing the period 1989-2002, for example, provide confirmation that concentrations of $\mathrm{Na}^{+}$and $\mathrm{MS}^{-}$(the two ions most clearly related to sea salt) decrease with distance from the coast within Victoria Valley and among glaciers of the Asgaard Range (Table 1). In Victoria Valley, analyte concentrations from the pits described here on Victoria Upper Glacier and Clark Glacier fit well into the decreasing trend described in Bertler and others (2004b) for Wilson Piedmont Glacier (WPG), Victoria Lower Glacier (VLG) and Baldwin Valley Glacier (BVG). A similar comparison can be made in the Asgaard Range comparing data from Commonwealth Glacier with data collected from Newall Glacier (Welch, 1993). This comparison likewise confirms that given presumably similar soil influences (both sites reside on the ridge between Taylor and Wright Valleys), opposing trends in elevation and species concentration dominate. The time period for the Newall record does not intersect with the time period covered here, but significantly lower values for all ions on Newall Glacier relative to Commonwealth Glacier 
likely represent a real trend, given the large difference in elevation and proximity to valley soil material between the two sites. The lower $\mathrm{Na}: \mathrm{Cl}$ ratio also suggests more substantial sea-salt fractionation at Newall Glacier than at Commonwealth.

However, the adjacent exposed valleys and salt-rich soils of the MDV complicate the relationships between site chemistry and elevation or distance from the coast when data are compared among the Clark, Commonwealth, Blue and Victoria Upper sites. Based on the data collected at these four sites, when chemistry is compared among the valleys, rather than within a particular valley, concentration gradients no longer exist with respect to either of these variables. The Commonwealth Glacier snow pit, for example, which is only $12.5 \mathrm{~km}$ from the coast and at 723 ma.s.l. has lower values for $\mathrm{Na}^{+}$than does the Clark Glacier pit, which is $30 \mathrm{~km}$ from the coast and $816 \mathrm{~m}$ a.s.l. Blue Glacier, $25 \mathrm{~km}$ from the coast and at $1022 \mathrm{ma.s.l.}$ likewise yields lower values for $\mathrm{Na}^{+}, \mathrm{Cl}^{-}$and $\mathrm{Mg}^{2+}$ than does Victoria Upper Glacier, $60 \mathrm{~km}$ from the coast and at $1350 \mathrm{~m}$ a.s.I.

Total concentrations of major ions generally decrease from north to south within $30 \mathrm{~km}$ of the coast. The most northerly site, Clark Glacier, has the highest values in seven of eight species, and the most southerly site, Blue Glacier, has the lowest values. Concentrations for Commonwealth Glacier fall inside the range of values for Blue and Clark Glaciers. $\mathrm{Ca}^{2+}$ provides the notable exception to this pattern, with Blue Glacier having the highest mean concentrations, 50\% higher than those found at Clark Glacier and $400 \%$ higher than those at Commonwealth.

Comparison with major-ion data from Lyons and others (2003) at Commonwealth Glacier highlights high intraannual and interannual variability in MDV chemistry. Disagreement between the data of Lyons and others (2003) and the results here is likely because the former study was conducted using surface samples, including in most cases $\sim 5 \mathrm{~cm}$ of surface snow collected in early austral summer (Lyons and others, 2003) and representing roughly half of the mean annual accumulation as calculated from the samples collected in our work. As described above, surface snow in the MDV during austral summer has peaks in $\mathrm{Na}^{+}$and several other ionic species. This dictates that the means of Lyons and others (2003) represent mean peak values, while the record presented here includes both lower 'background' winter values and these peak values. When the values of Lyons and others (2003) are compared with the peak values presented here, the results agree within sampling/timing errors (Fig. 6).

Non-sea-salt (nss) concentrations at these sites provide additional clues regarding variation in MDV snow chemistry. Concentrations of $\mathrm{Ca}: \mathrm{K}: \mathrm{Mg}: \mathrm{Na}: \mathrm{Cl}: \mathrm{SO}_{4}$ within each sample that conform to the sea-salt proportions of $1.04: 1.00: 3.24$ 27.00:55.00:7.76 are considered to derive from a sea-salt source. Non-sea-salt species are here defined as the amount of sample chemistry that cannot be explained using the above ratios (Legrand and Mayewski, 1997). Because it is possible that material other than sea-salt aerosols may have these analytes in the same proportions, the method used here provides a minimum estimate for non-sea-salt contribution to chemistry. Differences between total and non-sea-salt chemistry are most pronounced at Clark and Commonwealth Glaciers, where $\mathrm{Na}^{+}$and $\mathrm{Cl}^{-}$dominate the overall ion budget,
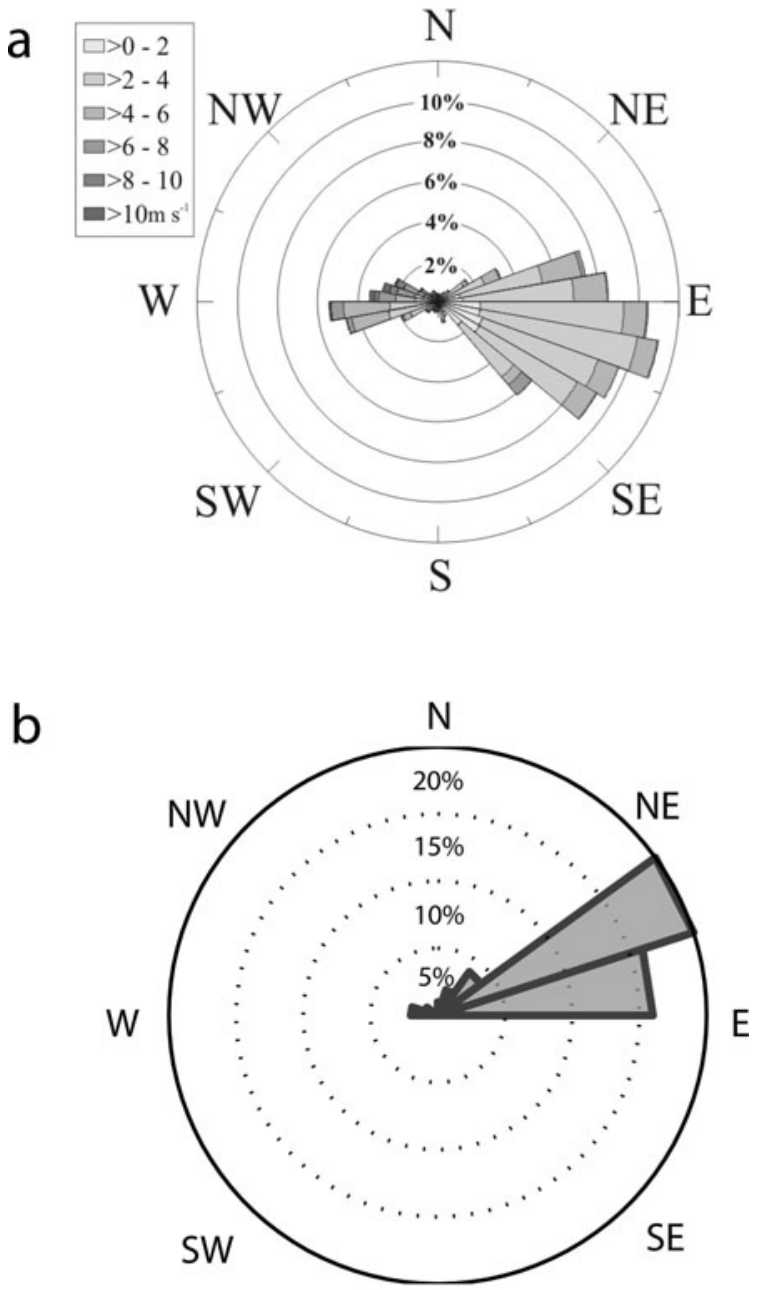

S

Fig. 5. Wind direction data from (a) Victoria Lower Glacier (Bertler and others, 2004b) and (b) Lake Brownworth (A.G. Fountain, http:// metacat.Iternet.edu/knb/metacat?action=read\&qformat=mcm\&docid= knb-lter-mcm.7005). Both panels represent the percentage of wind originating in the direction shown by each bin. Bin size for (a) is $10^{\circ}$; bin size for $(b)$ is $18^{\circ}$.

but $\mathrm{nsSSO}_{4}{ }^{2-}$ and $\mathrm{nssCa}^{2+}$ are the largest contributors for non-sea-salt species (Fig. 7). Non-sea-salt $\mathrm{Ca}^{2+}$ and nssSO ${ }_{4}{ }^{2-}$ dominate both the total $\mathrm{Ca}^{2+}$ and $\mathrm{SO}_{4}{ }^{2-}$ budgets and the total non-sea-salt ion budget at all four sites (though the mean nssCl- concentration at Commonwealth Glacier is not significantly different from that of $\mathrm{nssCa}^{2+}$ ). Values for $\mathrm{nssCa}^{2+}$ and $\mathrm{nssSO}_{4}{ }^{2-}$ at the sites are also from 120 to $>1000 \%$ higher than total (ss + nss) concentrations for these species on the nearby polar plateau (Steig and others, 2000; Bertler and others, 2004b), indicating that MDV ice contains local soil inputs in addition to those associated with long-range transport.

\section{Trace metals}

Of the trace metals analyzed for these sites, six will be discussed here, chosen to represent a variety of metal species. $\mathrm{Al}$ and $\mathrm{Fe}$, for example, represent the largest absolute contributions to the MDV metal budget, $\mathrm{Sr}$ is abundant in both the terrestrial and the marine environment, and oxides of Mn play a key role in particle scavenging of trace elements in MDV lake water (De Carlo and Green, 


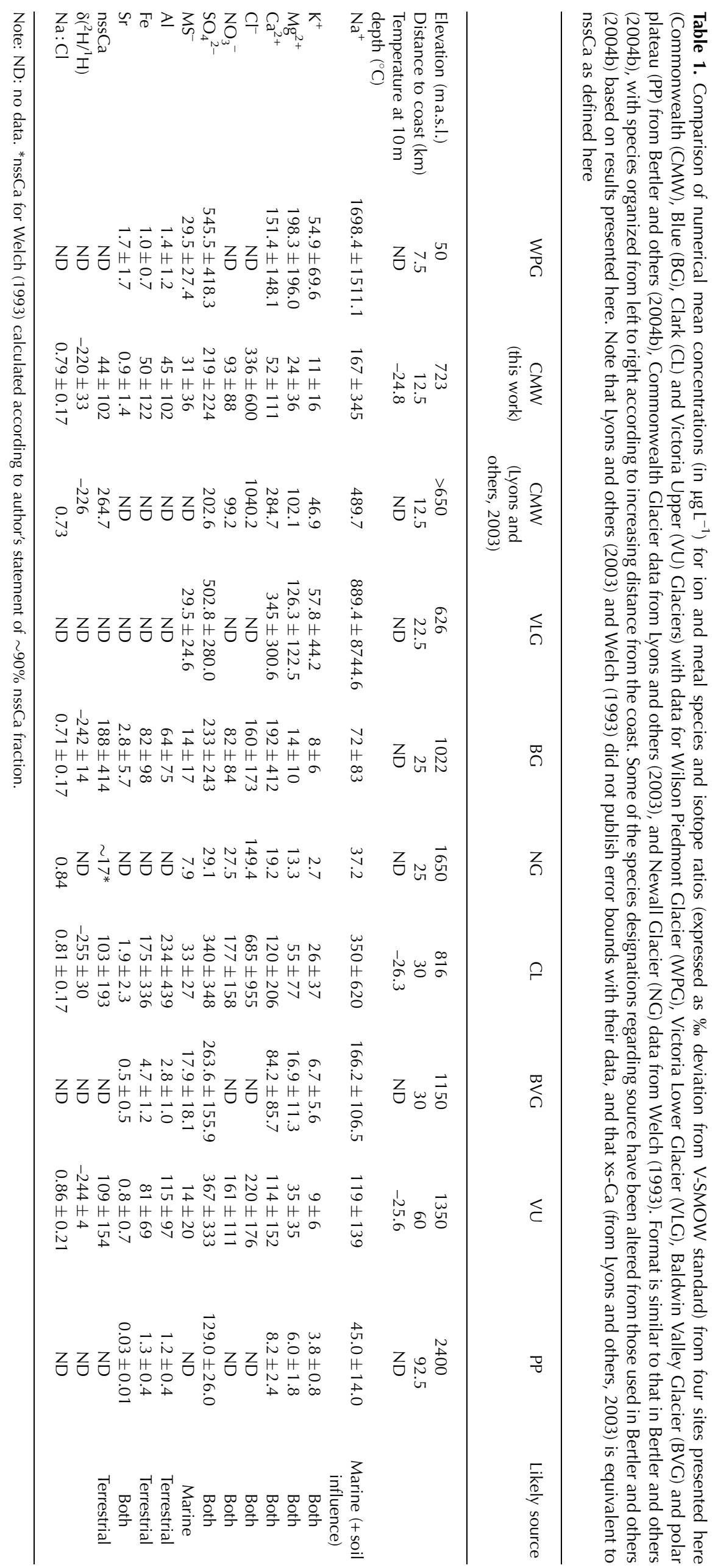



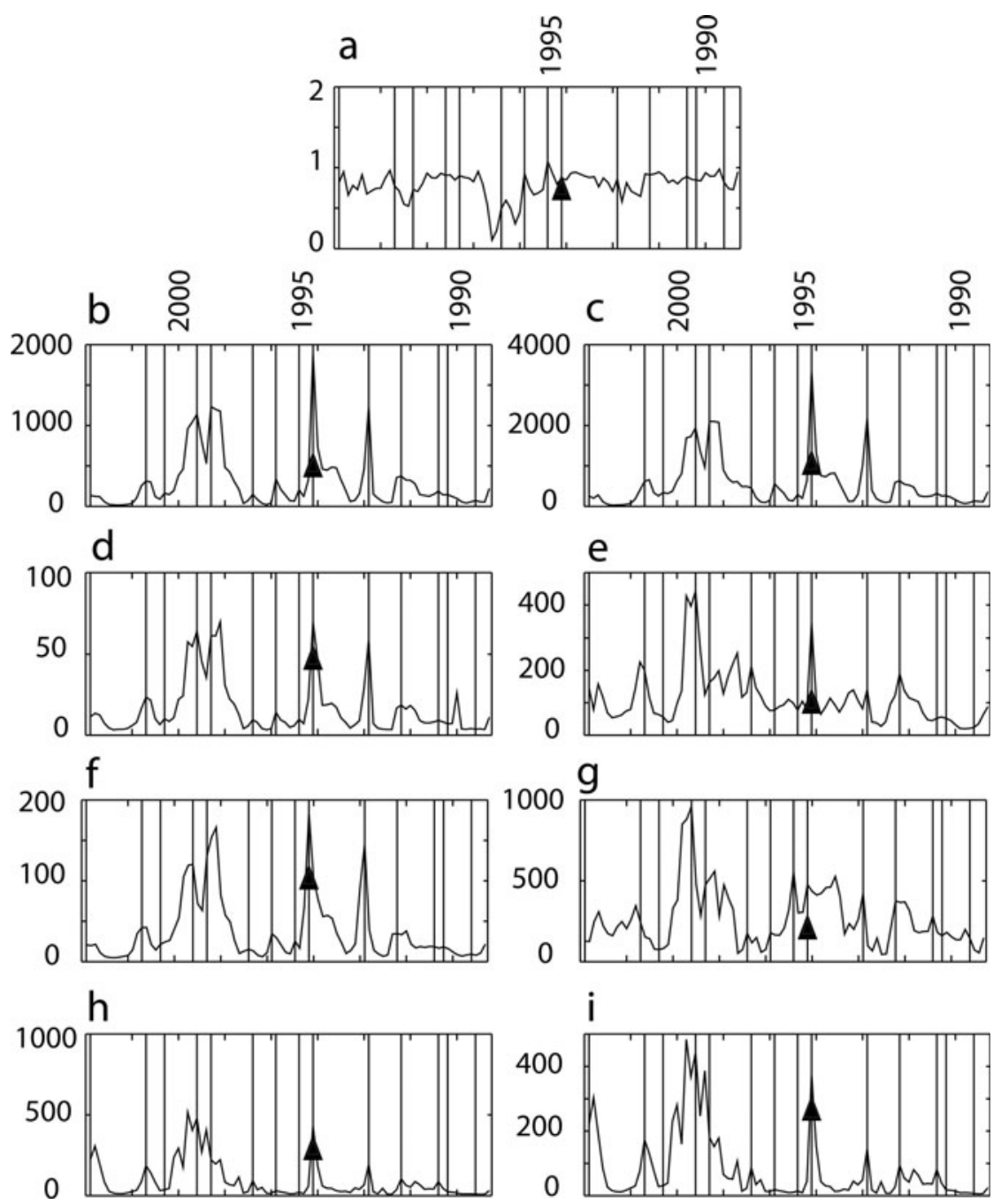

Fig. 6. Mean major-ion concentrations from Lyons and others (2003) (black triangles) plotted within the annually dated records reported here for (a) $\mathrm{Na}: \mathrm{Cl}$, (b) $\mathrm{Na}^{+}$, (c) $\mathrm{Cl}^{-}$, (d) $\mathrm{K}^{+}$, (e) $\mathrm{NO}_{3}{ }^{-}$, (f) $\mathrm{Mg}^{2+}$, (g) $\mathrm{SO}_{4}{ }^{2-}$, (h) $\mathrm{Ca}^{2+}$ and (i) $\mathrm{nssCa}^{2+}$. The data from Lyons and others (2003) were collected in the three summer seasons surrounding 1994/-95. These seasons recorded some of the highest peaks in the record in most ions. The data from Lyons and others (2003) were translated from $\mu \mathrm{mol} \mathrm{L}^{-1}$ to $\mu \mathrm{g} \mathrm{L}^{-1}$ for comparison in all cases except $\mathrm{Na}: \mathrm{Cl}$, where the data presented here were translated into $\mu \mathrm{mol} \mathrm{L}^{-1}$ to compare ratios.

2002). $\mathrm{Cu}$ and $\mathrm{Nd}$ here represent examples of trace constituents and the REE. All metals, except Sr, occur in MDV snow and ice in ratios relative to the major ions orders of magnitude higher than exist in sea water (Weisel and others, 1984; Abollino and others, 2001).

Samples from Clark Glacier have either the highest or near-highest mean concentrations for these sites in all of these metals except $\mathrm{Sr}$; samples from Commonwealth Glacier have among the lowest metal concentrations. Concentrations of $\mathrm{Fe}$ at all sites are comparable to values found by Mayewski and Lyons (1982) $\left(\sim 20-270 \mu \mathrm{g} \mathrm{L}^{-1}\right)$ in a study of Meserve Glacier covering 370years of MDV climate history. However, they are substantially higher than concentrations reported by Bertler and others (2004b) in a survey of snow pits (covering 20-35 years) from four sites in Victoria Valley. Because three of the sites in that study were either on the polar plateau or on glaciers in closer proximity to the coast, these concentrations may represent more direct coastal or plateau influences than do concentrations from the sites described here, which are located in closer proximity to the uncovered valley floors and farther from the Ross Sea.
In order to examine chemical variation in the insoluble particulate fraction at these sites, enrichment factors relative to $\mathrm{Al}$ are defined as:

$$
E_{X}=\frac{C_{X \text {-sample }} / C_{\mathrm{Al}-\text { sample }}}{C_{X \text {-upper crust }} / C_{\mathrm{Al} \text {-upper crust }}},
$$

where $C$ is the concentration of the metal in question (in $\mu \mathrm{L} \mathrm{L}^{-1}$ ), and listed in Table 2. These enrichment factors yield a complex picture, but among the four metals with the highest concentrations ( $\mathrm{Al}, \mathrm{Fe}, \mathrm{Sr}$ and $\mathrm{Mn}$ ), ratios are closer to values for the upper crust (Wedepohl, 1995) at the more northern sites, with the Clark and Victoria Upper sites being closest to these values. These trends may represent either an increasing soil influence to the north, different soil types at the four sites, or soil particulate fractionation during transport.

\section{DISCUSSION}

Spatial differences in mean chemistry among the sites presented here can be divided into differences between two sites along a west-east axis (Victoria Upper and Clark 


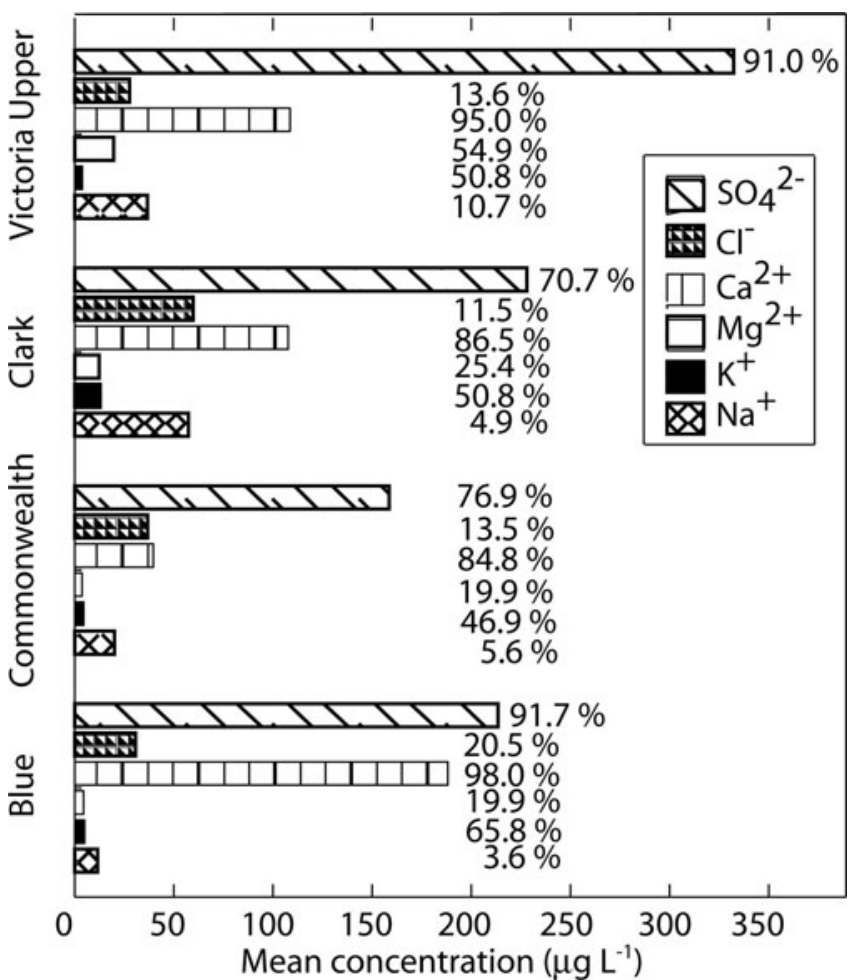

Fig. 7. Non-sea-salt components of $\mathrm{Na}^{+}, \mathrm{K}^{+}, \mathrm{Mg}^{2+}, \mathrm{Ca}^{2+}, \mathrm{Cl}^{-}$and $\mathrm{SO}_{4}{ }^{2-}$ at Victoria Upper, Clark, Commonwealth and Blue Glaciers. Bars represent absolute concentration in $\mu \mathrm{g} \mathrm{L}^{-1}$, while the value beside each bar describes the percentage of that ion found in nonsea-salt material relative to the total amount of the ion measured (e.g. on Victoria Upper Glacier, $91 \%$ of $\mathrm{SO}_{4}{ }^{2-}$ is determined to be of non-sea-salt origin, while $9 \%$ is calculated as the sea-salt contribution).

Glaciers) and differences among three sites along a coastal north-south axis (Clark, Commonwealth and Blue Glaciers). Data from the east-west sites examined here confirm previously documented trends in concentrations in Victoria Valley based on distance to the Ross Sea and on elevation. However, while Bertler and others (2004b) classified $\mathrm{K}^{+}$, $\mathrm{Mg}^{2+}$ and $\mathrm{Sr}$ as marine species, at the sites discussed here it appears these ions share a mixed terrestrial/marine source. Though mean concentration differences between Bertler and others (2004b) and this work might be explained by slightly different time periods covered by pits, the likelihood of soil influence playing a role is supported by non-sea-salt species analysis, in which calculated $\mathrm{nssMg}^{2+}$ comprises $25-50 \%$ of total $\mathrm{Mg}^{2+}$ and $\mathrm{nssK}^{+}$comprises $\sim 50 \%$ of total $\mathrm{K}^{+}$at the Clark and Victoria Upper sites.

When compared with the work by Mayewski and others (1995) and Welch (1993) on Newall Glacier, these results also suggest similar geographically driven trends within the glaciers of the Asgaard Range. However, the data presented here also support the hypothesis of Welch (1993) that relatively high values for $\mathrm{Ca}^{2+}$ and $\mathrm{SO}_{4}{ }^{2-}$ at Newall Glacier (NG in Fig. 1) are related to the nearby MDV soil source. Welch (1993) found $\sim 90 \% \mathrm{nssSO}_{4}{ }^{2-}$, which is the same value found here for Blue and Victoria Upper Glaciers.

When examined alongside these relationships among mean chemistry data, elevation and distance from the coast within the Asgaard Range and the Victoria Valley, the lack of chemistry trends following these two variables along the axis of the coast suggests separate dominant influences. The
Table 2. Metal:Al ratios for Clark, Commonwealth, Blue and Victoria Upper Glaciers, and enrichment factors associated with these ratios. Upper crust values from Wedepohl (1995)

\begin{tabular}{|c|c|c|c|c|c|}
\hline & $\mathrm{CL}$ & CMW & $B \mathrm{~L}$ & $\mathrm{VU}$ & Crust \\
\hline $\mathrm{C}_{\mathrm{Fe}}: \mathrm{C}_{\mathrm{Al}}$ & 0.76 & 1.11 & 1.33 & 0.66 & 0.40 \\
\hline $\mathrm{C}_{\mathrm{Sr}}: \mathrm{C}_{\mathrm{Al}}$ & 0.01 & 0.02 & 0.05 & 0.01 & 0.004 \\
\hline$C_{M n}: C_{A I}$ & 0.01 & 0.02 & 0.03 & 0.01 & 0.01 \\
\hline $\mathrm{C}_{\mathrm{Cu}}: \mathrm{C}_{\mathrm{Al}}$ & 0.002 & 0.0004 & 0.0008 & 0.008 & 0.0001 \\
\hline$C_{\mathrm{Nd}}: \mathrm{C}_{\mathrm{Al}}$ & 0.002 & 0.002 & 0.003 & 0.004 & 0.0003 \\
\hline$E_{\mathrm{Fe}}$ & 1.9 & 2.775 & 3.325 & 1.65 & \\
\hline$E_{\mathrm{Sr}}$ & 2.5 & 5.0 & 12.5 & 2.5 & \\
\hline$E_{\mathrm{Mn}}$ & 1.0 & 2.0 & 3.0 & 1.0 & \\
\hline$E_{\mathrm{Cu}}$ & 20.0 & 4.0 & 8.0 & 80.0 & \\
\hline$E_{\mathrm{Nd}}$ & 6.7 & 6.7 & 10.0 & 13.3 & \\
\hline
\end{tabular}

simplest explanation for north-south variation at these sites lies in the different local exposures to soil and marine sources from which they draw material. Because soil salt chemistry within the Dry Valleys varies spatially (Claridge and Campbell, 1977; Keys and Williams, 1981; Bockheim, 1997), we would expect to see a correspondingly complex influence on snow and firn chemistry. However, examination of published data describing the salt composition of a wide selection of MDV soil samples reveals some common patterns. In particular, ratios between $\mathrm{Mg}: \mathrm{K}$ and $\mathrm{Ca}: \mathrm{K}$ are both higher in all MDV soil samples than they are in sea salt (Fig. 8) (Claridge and Campbell, 1977; Keys and Williams, 1981; Bockheim, 1997; Abollino and others, 2001). The magnitude of these ratios also provides an identifiable pattern, with marine material showing a $\mathrm{Mg}: \mathrm{K}$ ratio higher than the $\mathrm{Ca}: \mathrm{K}$ ratio, and soil material showing the opposite. The relationship between $\mathrm{Mg}: \mathrm{K}$ and $\mathrm{Ca}: \mathrm{K}$ in the snow and firn examined here is similar to that shown by samples from the soil source (though lower in magnitude), highlighting the influence of valley soils in determining solute chemistry at these sites.

Different influences from marine air masses further distinguish the chemistry of each site. $\mathrm{Na}^{+}, \mathrm{Cl}^{-}$and $\mathrm{MS}^{-}$ likely reflect this marine influence. Both Clark and Commonwealth Glaciers, where $\mathrm{Na}^{+}$and $\mathrm{Cl}^{-}$concentrations are highest, have uninterrupted corridors to the coast through which up-valley winds characterizing summer daytime ground-level flow can carry marine aerosols. Clark Glacier in particular has two exposures, through Victoria and Wright Valleys, leading to the highest concentrations of marine species at this site. Victoria Upper Glacier, though twice as far from the coast as the other sites, likewise sits at the head of Victoria Valley, which may funnel marine species inland. Blue Glacier, on the other hand, though relatively close to the coast, is sheltered from low-elevation marine air to the east by a coastal range of mountains with peaks from 800 to $1500 \mathrm{~m}$ elevation. The combination of this shelter from the marine environment and a presumed high-calcium soil source may give Blue Glacier its unique ion signature of high $\mathrm{Ca}^{2+}$ concentrations alongside low concentrations of other major ions relative to the other sites.

Although the close proximity of soil materials to snow surfaces in the MDV makes the examination of terrestrially derived particulates particularly critical, the Dry Valleys are not unique in the presence of these materials. In areas of Antarctica more remote from soil sources, a variety of 

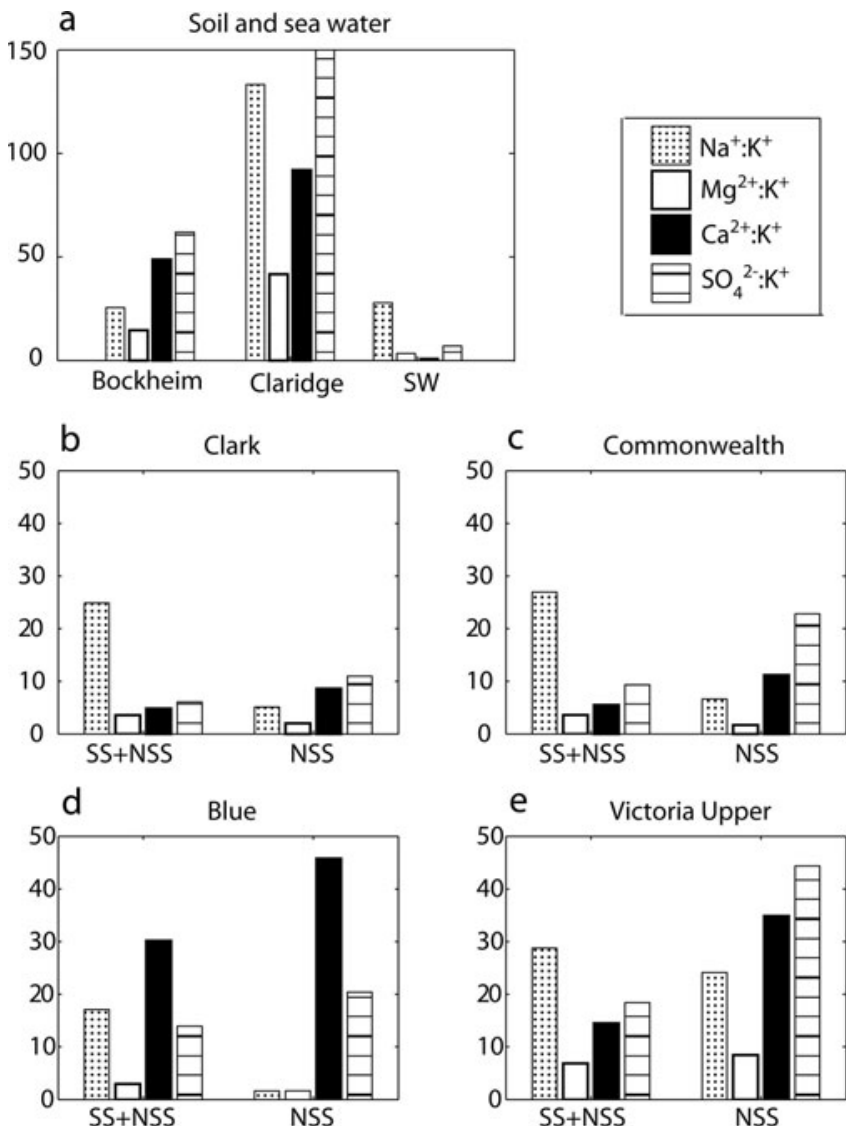

Fig. 8. Molar ion ratios of material collected at MDV sites (total $(=\mathrm{SS}+\mathrm{NSS})$ and the non-sea-salt component (=NSS)) compared with those of mean regional soil samples and of sea water. Bockheim mean ratios include data from eight sites (Bockheim, 1997), while Claridge mean ratios include data from 20 sites (Claridge and Campbell, 1977). Ratio of $\mathrm{SO}_{4}{ }^{2-}: \mathrm{K}^{+}$is 109 for the excess material at the Victoria Upper site, though axis was kept at 60 for purposes of comparison. Note that the scale is higher for soil samples (0-150) than for snow-pit samples (0-60).

studies have drawn conclusions regarding the likely provenance and the potential effects of insoluble trace metals (Boutron and Lorius, 1979; Boutron, 1982; Edwards and others, 1998; Edwards and Sedwick, 2001). The work here, however, demonstrates that the effect of this terrestrial material may not only be isolated to the classically 'terrestrial' elements, such as $\mathrm{Al}$ and Fe, but may also influence the chemistry of what are considered to be more 'marine' indicators, such as $\mathrm{Na}^{+}$or $\mathrm{Mg}^{2+}$. While calculations of the non-sea-salt fraction of these materials provides some accounting for this influence, the presence of terrestrial material coincident with these marine elements should be examined carefully when drawing conclusions regarding their climatic significance.

\section{CONCLUSIONS}

Snow pits excavated to 2 and $3 \mathrm{~m}$ at Victoria Upper, Clark, Commonwealth and Blue Glaciers in the Dry Valleys provide information on marine and local soil chemistry input into regional surface snow and firn. Measurements from additional pits at locations separated by hundreds of meters at Clark and Commonwealth Glaciers show significant variability, and require both marine and soil inputs to explain. Chronologies based on marine-species input, confirmed alongside mass accumulation rates measured directly by networks of mass-balance poles, show that these four sites share a common time frame of 1989-2002, with some of the sites having slightly longer coverage. Accumulation rates average 2.5, 3.4, 3.1 and $4.6 \mathrm{~cm}$ w.e. for Clark, Commonwealth, Blue and Victoria Upper sites, respectively; our interpretation of temporal data from Victoria Upper Glacier is offered with a caution regarding signs of potential subsurface melting at this location.

A survey of mean chemistry among the sites shows Clark and Commonwealth Glaciers with the highest concentrations in marine species (350 and $167 \mu \mathrm{g} \mathrm{L}^{-1}$ for $\mathrm{Na}^{+}, 25$ and $21 \mu \mathrm{L} \mathrm{L}^{-1}$ for $\mathrm{MS}^{-}$), while Blue Glacier shows unexpectedly low concentrations $\left(72 \mu \mathrm{gL}^{-1} \mathrm{Na}^{+}, 10 \mu \mathrm{g} \mathrm{L}^{-1} \mathrm{MS}^{-}\right)$, likely related to shelter provided by a coastal range to the east. Trace metals are in highest abundance at Clark Glacier (Al concentration $=234 \mu \mathrm{gL}^{-1}$ ), with the lowest concentrations found at Commonwealth Glacier (Al concentration $=45 \mu \mathrm{g} \mathrm{L}^{-1}$ ). Major-ion concentrations at Victoria Upper, Clark and Commonwealth sites are in good agreement with previously published intra-valley trends in Victoria Valley and the Asgaard Range, showing broadly decreasing values with increasing distance from the coast and increasing elevation. However, along a north-south axis trends in chemistry following elevation and distance from the coast do not appear. Instead, variations related to different soil sources and exposures to the Ross Sea dominate coastal mean chemistry gradients at these sites.

The circumstances defining the MDV climate system, including the onshore-offshore wind regime, widespread aridity and exposed rock and soils, help to give the valleys their unique character. This character also creates a wide selection of individual snow and firn signatures within a small area. Understanding broader climate changes in this area will therefore require continuing attention to local variation in Dry Valleys ice-core and snow-pit locations so as to be able to determine the difference between regional climate change and local variability. These results also suggest caution is required in defining separation between 'marine' and 'terrestrial' signals in Antarctic ice and snow samples.

\section{ACKNOWLEDGEMENTS}

We thank all of the people who assisted in conducting this research. In particular, M. Wasckiewicz, T. Gacke, E. Osterberg, S. Arcone, T. Burdet and K. Lindemueller provided assistance at our field locations, without which this project would have been impossible. In addition, the assistance of Raytheon Polar Services Company and of the pilots and staff from PSI for helicopter support is greatly appreciated. For help with global positioning system (GPS) surveys and map generation, we thank B. Bartel and J. Walker, with the University Navstar Consortium (UNAVCO) and the United States Antarctic Program, respectively. Funding for this project was provided under US National Science Foundation Award OPP 0228052.

\section{REFERENCES}

Abollino, O., M. Aceto, C. La Gioia, C. Sarzanini and E. Mentasti. 2001. Spatial and seasonal variations of major, minor and trace elements in Antarctic seawater: chemometric investigation of variable and site correlations. Adv. Environ. Res., 6(1), 29-43. 
Armienti, P., M. Tamponi and M. Pompilio. 2001. Sand provenance from major and trace element analyses of bulk rock and sand grains from CRP-2/2A, Victoria Land Basin, Antarctica. Terra Antarct., 8(4), 569-582.

Bertler, N.A.N., P.J. Barrett, P.A. Mayewski, R.L. Fogt, K.J. Kreutz and J. Shulmeister. 2004a. El Niño suppresses Antarctic warming. Geophys. Res. Lett., 31(15), L15207. (10.1029/ 2004GL020749.)

Bertler, N.A.N., P.A. Mayewski, P.J. Barrett, S.B. Sneed, M.J. Handley and K.J. Kreutz. 2004b. Monsoonal circulation of the McMurdo Dry Valleys, Ross Sea region, Antarctica: signal from snow chemistry. Ann. Glaciol., 39, 139-145.

Bertler, N.A.N., P.J. Barrett, P.A. Mayewski, R.L. Fogt, K.J. Kreutz and J. Shulmeister. 2005a. Reply to comment by Doran et al. on 'El Niño suppresses Antarctic warming'. Geophys. Res. Lett., 32(7), L07707. (10.1029/2005GL022595.)

Bertler, N.A.N. and 53 others. 2005b. Snow chemistry across Antarctica. Ann. Glaciol., 41, 167-179.

Bertler, N.A.N., T.R. Naish, H. Oerter, S. Kipfstuhl, P.J. Barrett and P.A. Mayewski. 2006. The effects of joint ENSO-Antarctic Oscillation forcing on the McMurdo Dry Valleys, Antarctica. Antarct. Sci., 18(4), 507-514.

Bockheim, J. 1997. Properties and classification of cold desert soils from Antarctica. Soil Sci. Soc. Am. Proc., 61, 224-231.

Boutron, C.F. 1982. Atmospheric trace metals in the snow layers deposited at the South Pole from 1928 to 1977. Atmos. Environ., 16(10), 2451-2459.

Boutron, C. and C. Lorius. 1979. Trace metals in Antarctic snows since 1914. Nature, 277(5697), 551-554.

Brandt, R.E. and S.G. Warren. 1993. Solar-heating rates and temperature profiles in Antarctic snow and ice. J. Glaciol., 39(131), 99-110.

Claridge, G.G.C. and I.B. Campbell. 1977. The salts in Antarctic soils, their distribution and relationship to soil processes. Soil Sci., 123(6), 377-384.

Crozaz, G., C.C. Langway, Jr and E. Picciotto. 1966. Artificial radioactivity reference horizons in Greenland firn. Earth Planet. Sci. Lett., 1(1), 42-48.

Curran, M.A.J. and 6 others. 2002. Post-depositional movement of methanesulphonic acid at Law Dome, Antarctica, and the influence of accumulation rate. Ann. Glaciol., 35, 333-339.

De Carlo, E.H. and W.J. Green. 2002. Rare earth elements in the water column of Lake Vanda, McMurdo Dry Valleys, Antarctica. Geochim. Cosmochim. Acta, 66(8), 1323-1333.

Dixon, D. and 6 others. 2005. A 200 year sulfate record from 16 Antarctic ice cores and associations with Southern Ocean seaice extent. Ann. Glaciol., 41, 155-166.

Doran, P.T. and 6 others. 2002. Valley floor climate observations from the McMurdo dry valleys, Antarctica, 1986-2000. J. Geophys. Res., 107(D24), 4772. (10.1029/2001JD002045.)

Edwards, R. and P. Sedwick. 2001. Iron in East Antarctic snow: implications for atmospheric iron deposition and algal production in Antarctic waters. Geophys. Res. Lett., 28(20), 3907-3910.

Edwards, R., P.N. Sedwick, V. Morgan, C.F. Boutron and S. Hong. 1998. Iron in ice cores from Law Dome, East Antarctica: implications for past deposition of aerosol iron. Ann. Glaciol., 27, 365-370.

Green, W.J., B.R. Stage, A. Preston, S. Wagers, J. Shacat and S. Newell. 2005. Geochemical processes in the Onyx River, Wright Valley, Antarctica: major ions, nutrients, trace metals. Geochim. Cosmochim. Acta, 69(4), 839-850.

Hall, B.L. and G.H. Denton. 2005. Surficial geology and geomorphology of eastern and central Wright Valley, Antarctica. Geomorphology, 64(1-2), 25-65.

Hall, B.L., G.H. Denton and C.H. Hendy. 2000. Evidence from Taylor Valley for a grounded ice sheet in the Ross Sea, Antarctica. Geogr. Ann., 82A(2-3), 275-303.

Hall, B.L., G.H. Denton, B. Overturf and C.H. Hendy. 2002. Glacial Lake Victoria, a high-level Antarctic lake inferred from lacustrine deposits in Victoria Valley. J. Quat. Sci., 17(7), 697-706.
Johnsen, S.J. 1977. Stable isotope homogenization of polar firn and ice. IAHS Publ. 118 (Symposium at Grenoble 1975 - Isotopes and Impurities in Snow and Ice), 210-219.

Keys, J.R. and K. Williams. 1981. Origin of crystalline, cold desert salts in the McMurdo region, Antarctica. Geochim. Cosmochim. Acta, 45(12), 2299-2309.

Kreutz, K.J. and P.A. Mayewski. 1999. Spatial variability of Antarctic surface snow glaciochemistry: implications for paleoatmospheric circulation reconstructions. Antarct. Sci., 11(1), 105-118.

Kreutz, K.J., P.A. Mayewski, S.I. Whitlow and M.S. Twickler. 1998. Limited migration of soluble ionic species in a Siple Dome, Antarctica, ice core. Ann. Glaciol., 27, 371-377.

Kreutz, K.J., P.A. Mayewski, I.I. Pittalwala, L.D. Meeker, M.S. Twickler and S.I. Whitlow. 2000. Sea level pressure variability in the Amundsen Sea region inferred from a West Antarctic glaciochemical record. J. Geophys. Res., 105(D3), 4047-4059.

Lancaster, N. 2002. Flux of eolian sediment in the McMurdo Dry Valleys, Antarctica: a preliminary assessment. Arct. Antarct. Alp. Res., 34(3), 318-323.

Landis, G.P., J.J. Fitzpatrick and T. Everett. 1995. Analysis of firn gases collected at shallow depths in the Wrangell-St. Elias range, Alaska, the GISP2 site, Greenland, and the Taylor Dome site, East Antarctica. USGS Open File Rep. 95-222.

Legrand, M.R. and R.J. Delmas. 1984. The ionic balance of Antarctic snow: a 10 year detailed record. Atmos. Environ., 18(9), 1867-1874.

Legrand, M.R. and R.J. Delmas. 1988. Formation of $\mathrm{HCl}$ in the Antarctic atmosphere. J. Geophys. Res., 93(D6), 7153-7168.

Legrand, M. and P. Mayewski. 1997. Glaciochemistry of polar ice cores: a review. Rev. Geophys., 35(3), 219-243.

Lyons, W.B., K.A. Welch, A.G. Fountain, G.L. Dana, B.H. Vaughn and D.M. McKnight. 2003. Surface glaciochemistry of Taylor Valley, southern Victoria Land, Antarctica and its relationship to stream chemistry. Hydrol. Process., 17(1), 115-130.

Mayewski, P.A. and W.B. Lyons. 1982. Source and climatic implication of the reactive iron and reactive silicate concentrations found in a core from Meserve Glacier, Antarctica. Geophys. Res. Lett., 9(3), 190-192.

Mayewski, P.A. and 11 others. 1995. An ice-core-based, Late Holocene history for the Transantarctic Mountains, Antarctica. In Elliot, D.H. and G.L. Blaisdell, eds. Contributions to Antarctic research IV. Washington, DC, American Geophysical Union, 33-45. (Antarctic Research Series 67.)

Mayewski, P.A. and 13 others. 1996. Climate change during the last deglaciation in Antarctica. Science, 272(5268), 1636-1638.

McKendry, I.G. and E.W.D. Lewthwaite. 1990. The vertical structure of summertime local winds in the Wright Valley, Antarctica. Bound.-Layer Meteorol., 51(4), 321-342.

Mulvaney, R. and E.W. Wolff. 1994. Spatial variability of the major chemistry of the Antarctic ice sheet. Ann. Glaciol., 20, 440-447.

Mulvaney, R., E.C. Pasteur, D.A. Peel, E.S. Saltzman and P.Y. Whung. 1992. The ratio of MSA to non-sea-salt sulphate in Antarctic Peninsula ice cores. Tellus, 44B(4), 295-303.

Pasteur, E.C. and R. Mulvaney. 1999. Laboratory study of the migration of methane sulphonate in firn. J. Glaciol., 45(150), 214-218.

Pasteur, E.C. and R. Mulvaney. 2000. Migration of methane sulphonate in Antarctic firn and ice. J. Geophys. Res., 105(D9), 11,525-11,534.

Smith, B.T., T.D. van Ommen and M.A.J. Curran. 2004. Methanesulphonic acid movement in solid ice cores. Ann. Glaciol., 39, 540-544.

Stager, J.C. and P.A. Mayewski. 1997. Abrupt early to midHolocene climatic transition registered at the Equator and the Poles. Science, 276(5320), 1834-1836.

Steig, E.J., C.P. Hart, J.W.C. White, W.L. Cunningham, M.D. Davis and E.S. Saltzman. 1998a. Changes in climate, ocean and icesheet conditions in the Ross embayment, Antarctica, at $6 \mathrm{ka}$. Ann. Glaciol., 27, 305-310.

Steig, E.J. and 8 others. 1998b. Synchronous climate changes in Antarctica and the North Atlantic. Science, 282(5386), 92-95. 
Steig, E.J. and 7 others. 2000. Wisconsinan and Holocene climate history from an ice core at Taylor Dome, western Ross Embayment, Antarctica. Geogr. Ann., 82A(2-3), 213-235.

Steig, E.J. and 16 others. 2005. High-resolution ice cores from US ITASE (West Antarctica): development and validation of chronologies and determination of precision and accuracy. Ann. Glaciol., 41, 77-84.

Sucher, C. 1997. Atmospheric gases in the Taylor Dome ice core: implications for East Antarctic climate change. (MSc thesis, University of Rhode Island.)

Thompson, D.C., R.M.F. Craig and A.M. Bromley. 1971. Climate and surface heat balance in an Antarctic dry valley. New Zeal. J. Geol. Geophys., 14(2), 245-251.

Wagenbach, D. and 7 others. 1998. Sea-salt aerosol in coastal Antarctic regions. J. Geophys. Res., 103(D9), 10,961-10,974.

Wedepohl, K.H. 1995. The composition of the continental crust. Geochim. Cosmochim. Acta, 59(7), 1217-1232.
Weisel, C.P., R.A. Duce, J.L. Fasching and R.W. Heaton. 1984. Estimates of the transport of trace metals from the ocean to the atmosphere. J. Geophys. Res., 89(D7), 11,607-11,618.

Welch, K.A. 1993. Glaciochemical investigations of the Newall Glacier, southern Victoria Land, Antarctia. (MS thesis, University of New Hampshire.)

Welch, K.A., P.A. Mayewski and S.I. Whitlow. 1993. Methanesulfonic acid in coastal Antarctic snow related to sea ice extent. Geophys. Res. Lett., 20(6), 443-446.

Williamson, B. 2006. Sources and deposition processes linking atmospheric chemistry and firn records from four glaciers accumulation zones in the McMurdo Dry Valleys, Antarctica. (MS thesis, University of Maine.)

Yang, Q., P.A. Mayewski, E. Linder, S. Whitlow and M. Twickler. 1996. Chemical species spatial distribution and relationship to elevation and snow accumulation rate over the Greenland ice sheet. J. Geophys. Res., 101(D13), 18,629-18,637.

MS received 12 January 2007 and accepted in revised form 1 July 2007 